\title{
VALLEY BOTTOM CLAY DISTRIBUTION AND ADAPTED DRAINAGE TECHNIQUES
}

\author{
Amadou Keïta ${ }^{1}$, Laszlo G. Hayde ${ }^{2}$, Hamma Yacouba ${ }^{3}$ and Bart Schultz ${ }^{4}$
}

\begin{abstract}
Waterlogged valley bottom soils of Tropical Savannah are areas where the richest traditional cropping systems are found, but they also face adverse physico-chemical conditions which can drastically drop rice yield. Subsurface drainage has been used for many areas to alleviate waterlogging. However, this drainage is dependent on clay distribution, type and location. The current paper analyses these factors for the case of Tiefora, a 16 ha valley bottom irrigated rice scheme in Burkina Faso. For this purpose, nine boreholes, with depths from 2 to $6 \mathrm{~m}$, were realised. A total of 51 samples of soils were extracted at various depths, based on soil changes in texture and colour. These samples underwent grain-size-analysis. A comparative non-linear regression was performed on the clay distribution. Quadratic regression was the most appropriate. In addition, clay proportions were high - 20-30\% in the $2 \mathrm{~m}$ topsoil - in the upstream and middle areas. A more important - 30-40\% - peak was reached in the downstream area at $1 \mathrm{~m}$, with a much smaller thickness (less than $50 \mathrm{~cm}$ ) and higher permeability. These results suggest the application of mole drainage in the valley, except downstream where the classical Hooghoudt pipe subsurface drainage can be implemented.
\end{abstract}

Keywords: Clay distribution, drainage, non-linear regression, permeability, Tropical Savannah, valley bottoms.

\section{INTRODUCTION}

Valley bottom soils are among the first ones used spontaneously by farmers in West-Africa to grow rice, though growing adverse conditions occur year after year (Nguu et al. 1988; Dembele et al. 2012; Keïta et al. 2013b). Several millions of hectares of rice growing valley bottoms face stresses and toxicities due to anoxic conditions (Becker and Asch 2005). For example, the West Africa Rice Development Association (WARDA, now called "Africa Rice") estimated that at least $60 \%$ of the swampy cultivated inland areas of Africa are affected by varying degrees of iron toxicity (Sahravat et al. 1996). The average rice yield has been estimated to 2.5-3.0 tons/ha for irrigated rice and this figure is even lower in Burkina Faso (Ouattara 1992).Various researchers brought important contributions to the characterization of valley bottom waterlogged soils by using different parameters (Kessler and Oosterbaan 1974; Barron and Torrent 1986; Ogban and Babalola 2009). For example, Barron and Torrent (1986) attempted to provide visual observation criteria for waterlogging. Other parameters of valley bottom soils linked to infiltration processes such as the texture and the saturated hydraulic conductivity $K_{\text {sat }}$ were studied (Kessler and Oosterbaan 1974), often more in view of classification of valley bottoms and their crop land suitability mapping.

Even though clay plays a key role (Robinson et al. 1987) in aerated water circulation through valley bottom soils, previous research in Tropical Savannah of West Africa remained silent about its distribution. Hardly can be found any study providing detailed information about clay spreading within the soil and its connection with subsurface drainage issues. The current paper considers such connections by applying non-linear regression analysis to describe clay distribution, and proposes the most appropriate drainage technique for each situation met.

\section{MATERIALS AND METHODS}

Sites Location

\footnotetext{
${ }^{1}$ Department of Hydraulics, International Institute for Water and Environmental Engineering (2iE), Ouagadougou, 01 BP 594 Ouaga 01, BURKINA FASO, amadou.keita@2ie-edu.org

${ }^{2}$ Department of Water Science and Engineering, UNESCO-IHE- Institute for Water Education, Delft, PO Box 3015, 2601 DA, Delft, THE NETHERLAND, b.schultz@unesco-ihe.org

${ }^{3}$ Department of Hydraulics, International Institute for Water and Environmental Engineering (2iE), Ouagadougou, 01 BP 594 Ouaga 01, BURKINA FASO, hamma.yacouba@2ie-edu.org

${ }^{4}$ IALT member, Department of Water Science and Engineering, UNESCO-IHE- Institute for Water Education, Delft, PO Box 3015 , 2601 DA, Delft, THE NETHERLAND, b.schultz@unesco-ihe.org

Note: Discussion on this paper is open until June 2015
} 
Tiéfora (4³3'13.19" longitude West and $10^{\circ} 37^{\prime} 33.56$ " latitude North) is a "full water controlled" valley bottom irrigation system for rice production playing a central socio-economical role. Irrigation water is delivered to the valley through a $800 \mathrm{~m}$ long earthen open canal, bordered by a small gallery of forest. This canal withdraws water from an earth dam of $500000 \mathrm{~m}^{3}$ constructed in 1962 (ONBAH 1987). The 16 ha-farming system of the valley (Fig.1) produces rice in both the rainy (June-October) and the dry seasons (April-May) for 34 families. The rice produced in the scheme is partly commercialized, and is partly used to prepare meals when the families receive important guests. Rice production is a privilege, even though the village of Tiéfora produces also around the valley a considerable amount of mangoes, harvested at the end of the dry season. The rice yield - due essentially to the occurrence of iron toxicity and a certain acidity of the hematite soils (Sokona et al. 2010) - is generally less than 4 tons/ha.

\section{Soil Sampling}

In the 50 years old valley bottom, anticipating a heterogeneous soil requiring several samplings, two main types of boring machines were prepared. When passing through a clayey and cohesive but non-saturated soil, the Edelman auger of $70 \mathrm{~mm}$ of diameter was used. Across saturated soils under the groundwater table, in layers with sand or gravelly non-cohesive material, the Riverside auger of $70 \mathrm{~mm}$ diameter was used. Extension bars of 1 meter length with coupling sleeves were connected to the auger at the bottom and were operated on the top using a screwable handle. Nine boreholes of 2-6 $\mathrm{m}$ depth were dug, three located in each of the upstream, middle and downstream cross sections (Fig.1).

A total of 51 samples were collected using an undisturbed soil sampler tool any time there was a change in visual color or in the structure (scratching the fingers) of the soil, all along the borehole. The number of samples varied from five to eight, according to the

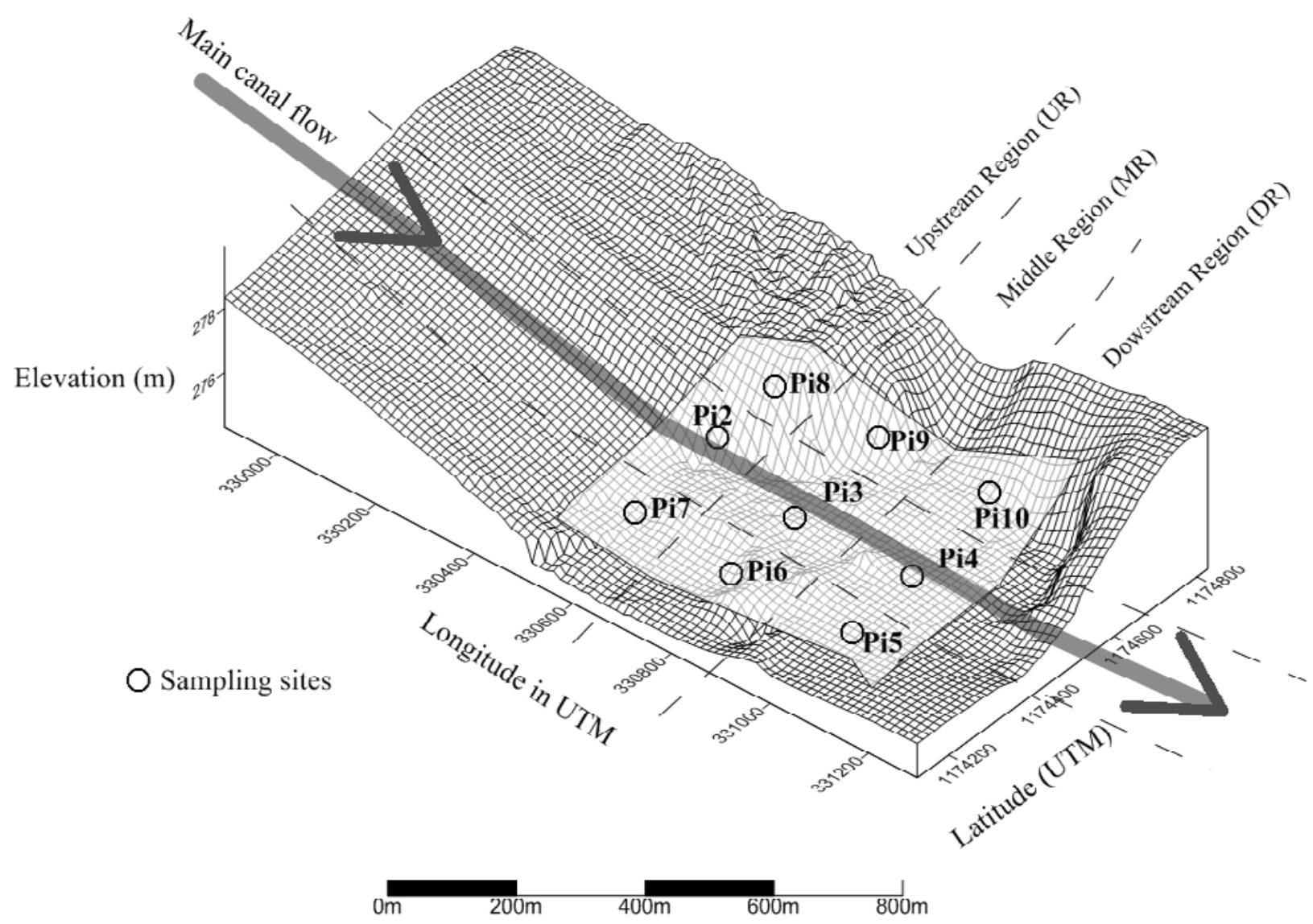

Fig. 1 The three cross sections and the location of the nine boreholes of the valley bottom. The circles represent the boreholes realized in the three areas delineated by the three cross sections (UR, MR and DR). Pix represents the name of the borehole. The cross sections are located some $300 \mathrm{~m}$ from each other (Keita et al. 2013a). 
previous criteria. The collected soil samples were taken to the laboratory for grain size analyses.

The US Department of Army's classification (USDA 1997) was used to isolate clays particles smaller than $0.002 \mathrm{~mm}(2 \mu \mathrm{m})$. The processing according to this classification obeys the following rules: clays are particles smaller than $0.002 \mathrm{~mm}(2 \mu \mathrm{m})$, silt are grains with diameter between 0.002 and $0.02 \mathrm{~mm}(20 \mu \mathrm{m})$ and all grains between $0.02 \mathrm{~mm}$ and $2 \mathrm{~mm}$ are total sand (fine sand + coarse sand). Between $2 \mathrm{~mm}$ and $11 \mathrm{~mm}$ are gravels, and above $11 \mathrm{~mm}$ are classified stones.

\section{Statistical Analysis}

With the aim to determine the most suitable regression curve for the clay distribution in the soil, the statistical analysis compared two non-linear models: the cubic and the quadratic. This analysis was performed using the statistical software package GraphPad Prism $v 5$. The program makes a statistical comparison between the regression curves on the basis of the coefficients used in their equations (Keïta 2014).

Three criteria were mainly used to compare the two models. The goodness of fit of the model was the first. When the curves were equivalent in this regard, the simplicity of the model was the next criterion. The last criterion consisted in the practical value of the parameters in terms of subsurface drainage. The complexity of sample extractions led to the limitation of their number per borehole to less than ten. Despite of this limitation, the goodness of fit of the models was assessed based on three parameters. The first was the curve goodness of fit evaluated using the coefficient of determination $\mathrm{R}^{2}$ and the standard deviation of the residuals Syx (Montgomery and Runger 2011). Secondly, the test of normality of the residuals according to Shapiro -Wilk variables was applied (Shapiro and Wilk 1965). Finally, the Runs test method was used to evaluate how much the data points deviate from the best fit curves (McWilliams 1990).

Once the most suitable regression curve was determined, the analyses strove to compare the clay profile similarities in the soil. Taking into account the sedimentation in topo sequence inside the valley, which in the current case is from downstream to upstream, (Keïta et al. 2014), three transversal cross sections were defined according the locations of the nine boreholes. Consequently, an attempt was made to find a common regression model for each of the three cross sections. This comparison was based on the hypothesis testing of the regression equation parameters. When the hypothesis testing revealed significant differences for the entire set of parameters, the location of the maximum of the regression curves in the soil - which influences the type subsurface drainage technology to be adopted - was checked to conclude about similarities of the soils (Neumeyer and Dette 2003).

\section{RESULTS AND DISCUSSIONS}

\section{Soil Texture}

The colluvial and alluvial materials in the valley bottom reveal the predominance of clay in the top soil. For example, in the upstream cross section profile shown in Table 1 clay combinations dominate the first meters of the soil. Based solely on the grain size tables, it appears that the clay minerals percentage generally decreases as the depth increases. Clay content is particularly higher within the first meter in the soil. In this layer, the percentage of clay minerals is generally exceeds $20 \%$ and then decreases to less than $10 \%$ around $5 \mathrm{~m}$. The phenomenon is more visible in the regression analysis performed below. One can also notice that while the clay content decreases, the sand content increases (Table 1, column 7). In fact, the fine sand proportion reaches more than $40 \%$ around $5 \mathrm{~m}$ in most of the boreholes. Though one cannot predict what type of soil will be found after the sand layer, it appears that the impervious layer is located rather in the top than in the bottom, as shown in the associated USDA soil class reported in the last columns of Table 1, Table 2 and Table 3 . The first meter of the top soil is mainly formed by very fine material of clay loam and silty clay; these two classes having a common border in the USDA soil texture triangle. Remarkably, these results are contrary to the configuration - pervious layer overtopping impervious layer for example in peat dominant soils - generally found in literature about drainage system design (Christen and Ayars 2001).

\section{Finding a Regression Model}

The attempt to find a unique equation for all the nine boreholes was indeed statistically successful. The equation found was quadratic and expressed as follows:

$$
\operatorname{Clay}(\%)=30.6-7.3 d+0.9 d^{2}
$$

Where $d$ represents the depth expressed in meters. In the previous quadratic equation the coefficients are the following: $B_{0}=30.6 ; B_{1}=-7.3$ and $B_{2}=0.9$. The $90 \%$ confidence intervals for each of the three coefficients of the quadratic equation were respectively 25.9 to 35.3 for $B_{0},-12.90$ to -1.70 for $B_{1}$ and -0.20 to 1.90 for $B_{2}$ for all 
the nine boreholes. Based on a null hypothesis "One curve for all data sets" and an alternative hypothesis of "Different curve for each data set", the hypothesis testing comparing all the similar coefficients for each of the nine boreholes yielded a $\mathrm{p}$-value $45 \%$, greater than the significance level of $5 \%$. Therefore, the above unique regression curve Eq. (1) could be "accepted" (Montgomery and Runger 2011) .

Due to important dispersion of the data points and the necessity of finding a physical meaning to the equations, this unique non-linear regression curve was not finally kept. The coefficients of determination ranged from -3.0 (at borehole Pi8) to 0.6 (at borehole Pi3), with three out of nine negative values (Montgomery and Runger 2011).
The absolute sum of squares varied from 200 to 6000 , indicating a quite important dispersion of data points around the regression curve (Montgomery and Runger 2011). Finally, the inherent heterogeneity of the clay distribution within the profiles and the topo sequential deposition process of the sediments suggested a crosssectional approach (Fig.1), from upstream to downstream (Selley 2000). The regression curve coefficients are reported in Table 4.

Regression goodness of fit

Despite of limited number of data points - five to eight - per borehole (Table 1, Table 3 , and Fig.2) the goodness of fit based on the three sets of parameters mentioned above can be considered as good. The

Table 1 Upstream cross-section boreholes grain size distribution

\begin{tabular}{|c|c|c|c|c|c|c|c|c|}
\hline Sample No & $\begin{array}{c}\text { Depth } \\
\text { start (m) }\end{array}$ & $\begin{array}{l}\text { Depth end } \\
(\mathrm{m})\end{array}$ & $\begin{array}{c}\text { Clay } \\
\%\end{array}$ & $\begin{array}{c}\text { Silt } \\
\%\end{array}$ & $\begin{array}{c}\text { Gravel } \\
\% \\
\end{array}$ & $\begin{array}{c}\text { Sand total } \\
\%\end{array}$ & $\begin{array}{c}\text { Total } \\
\text { mater. } \\
\%\end{array}$ & $\begin{array}{c}\text { USDA Soil class } \\
\text { (Triangle) }\end{array}$ \\
\hline Piezo : & Pi7A & \multicolumn{2}{|c|}{ Geo coordinates UTM 30P : } & & $\mathrm{X}$ & 330592 & $\mathrm{Y}$ & 1174470 \\
\hline 39 & 0 & 0.1 & 25.8 & 25 & 9 & 49.2 & 100 & Sandy clay loam \\
\hline 40 & 0.1 & 0.3 & 28.1 & 38.4 & 0.1 & 33.5 & 100 & Clay loam \\
\hline 41 & 0.3 & 0.8 & 39.1 & 31.6 & 4 & 29.3 & 100 & Clay loam \\
\hline 42 & 0.8 & 2 & 10.7 & 36.1 & 0.2 & 53.2 & 100 & Sandy loam \\
\hline 43 & 2 & 4.3 & 7.4 & 37.4 & 0.2 & 55.2 & 100 & Silt \\
\hline 44 & 4.3 & 4.7 & 21 & 41.3 & 0.2 & 37.7 & 100 & Loam \\
\hline 45 & 4.7 & 5.3 & 17.9 & 47.7 & 0 & 34.4 & 100 & Loam \\
\hline Piezo : & $\mathrm{Pi} 2 \mathrm{~A}$ & \multicolumn{2}{|c|}{ Geo coordinates UTM 30P : } & & $\mathrm{X}$ & 330734 & Y & 1174547 \\
\hline 1 & 0 & 0.1 & 23.3 & 39.2 & 10 & 37.5 & 100 & Loam \\
\hline 2 & 0.1 & 0.3 & 30 & 43 & 1.1 & 27 & 100 & Clay loam \\
\hline 3 & 0.3 & 0.5 & 17.1 & 50.1 & 0.1 & 32.8 & 100 & Silt loam \\
\hline 4 & 0.5 & 1.3 & 25.4 & 32.8 & 0.1 & 41.8 & 100 & Loam \\
\hline 5 & 1.3 & 4 & 7.8 & 34.1 & 0.9 & 58.1 & 100 & Sandy loam \\
\hline Piezo : & Pi8A & \multicolumn{2}{|c|}{ Geo coordinates UTM 30P : } & & $\mathrm{X}$ & 330864 & $\mathrm{Y}$ & 1174659 \\
\hline 51 & 0 & 0.1 & 18 & 35 & 0.1 & 47 & 100 & Loam \\
\hline 52 & 0.1 & 0.3 & 16.9 & 51.7 & 0.2 & 31.4 & 100 & Silt loam \\
\hline 53 & 0.3 & 0.8 & 12.7 & 49.3 & 1 & 38 & 100 & Loam \\
\hline 54 & 0.8 & 2.2 & 21.7 & 38.3 & 0.2 & 40 & 100 & Loam \\
\hline 55 & 2.2 & 3.3 & 26.9 & 33.5 & 0.4 & 39.6 & 100 & Clay loam \\
\hline 56 & 3.3 & 4.4 & 13.1 & 23.3 & 0.3 & 63.6 & 100 & Sandy loam \\
\hline
\end{tabular}

The table contains data and computed results after grain size analysis. In the first column are reported the samples' ID as they were taken from the soil, the number representing actually the number carved on the sampling inox box. The second and the third columns data present the starting and the ending of a layer with identical texture and color. From column 4 to 7 are shown the grain distribution size calculation results from sieve analysis. In the column 9 - which is the last in the table - are shown the USDA soil triangle analysis results that determine the class of soil the layer belongs to. In the three internal lines of the table are shown the name of the piezometer and its geographical coordinates. The accuracy of the GPS measurements were $3 \mathrm{~m}$. This description of the table is similar for all the nine boreholes. 
Table 2 Middle cross-section boreholes grain size distribution

\begin{tabular}{|c|c|c|c|c|c|c|c|c|}
\hline Sample No & $\begin{array}{c}\text { Depth start } \\
(\mathrm{m})\end{array}$ & $\begin{array}{l}\text { Depth end } \\
(\mathrm{m})\end{array}$ & $\begin{array}{c}\text { Clay } \\
\%\end{array}$ & $\begin{array}{l}\text { Silt } \\
\%\end{array}$ & $\begin{array}{c}\text { Gravel } \\
\%\end{array}$ & $\begin{array}{c}\text { Sand total } \\
\%\end{array}$ & $\begin{array}{c}\text { Total mater. } \\
\% \\
\end{array}$ & $\begin{array}{c}\text { USDA Soil class } \\
\text { (Triangle) }\end{array}$ \\
\hline Piezo : & Pi6Abis & Geo coordina & UTM 30P : & & $\mathrm{X}$ & 330877 & $\mathrm{Y}$ & 1174344 \\
\hline 33 & 0 & 0.1 & 20.3 & 38.4 & 0 & 41.3 & 100 & Loam \\
\hline 34 & 0.1 & 0.3 & 38.9 & 29.1 & 0.4 & 32 & 100 & Clay loam \\
\hline 35 & 0.3 & 1.4 & 36.6 & 31.1 & 0 & 32.3 & 100 & Clay loam \\
\hline 36 & 1.4 & 2.4 & 13.6 & 37.6 & 0 & 48.8 & 100 & Loam \\
\hline 37 & 2.4 & 4.7 & 23.1 & 39.8 & 2.5 & 37.1 & 100 & Loam \\
\hline 38 & 4.7 & 6 & 20.3 & 30.4 & 1.3 & 49.3 & 100 & Loam \\
\hline Piezo : & Pi3A & Geo coordina & UTM 30P : & & $\mathrm{X}$ & $\mathrm{Y}$ & 330949 & 1174419 \\
\hline 6 & 0 & 0.1 & 31.5 & 42.4 & 0.3 & 26.1 & 100 & Clay loam \\
\hline 7 & 0.1 & 0.3 & 31.4 & 47 & 0.7 & 21.6 & 100 & Clay loam \\
\hline 8 & 0.3 & 1.3 & - & 45.3 & 0 & 38.3 & 100 & Loam \\
\hline 9 & 1.3 & 2.2 & 21 & 24.9 & 0.3 & 54.1 & 100 & Sandy clay loam \\
\hline 10 & 2.2 & 2.7 & 3.1 & 35.4 & 0 & 61.5 & 100 & Sandy loam \\
\hline Piezo : & Pi9A & Geo coordina & UTM 30P : & & $\mathrm{X}$ & $\mathrm{Y}$ & 3331113 & 1174514 \\
\hline 46 & 0 & 0.1 & 28 & 41 & 0.1 & 31 & 100 & Clay loam \\
\hline 47 & 0.1 & 0.3 & 37 & 44.2 & 0.1 & 18.8 & 100 & Silty clay loam \\
\hline 48 & 0.3 & 0.8 & 56.4 & 23.4 & 0.1 & 20.2 & 100 & Clay \\
\hline 49 & 0.8 & 2.9 & 31 & 42.4 & 1 & 26.6 & 100 & Clay loam \\
\hline 50 & 2.9 & 5.1 & 15.4 & 18.4 & 0.1 & 66.2 & 100 & Sandy loam \\
\hline
\end{tabular}

coefficient of determination $\mathrm{R}^{2}$ is greater than 0.5 for all the boreholes, except Pi5 and Pi6. However, particularly in a medium with high heterogeneity potentials, it is important to notice that goodness of fit cannot be limited to $\mathrm{R}^{2}$ (Montgomery and Runger 2011). Therefore, taking the analysis further, it appears that the normality test of the residuals led to Shapiro-Wilk coefficient Wp-values ranging from 27 to $38 \%$, all values greater than the significance $\mathrm{p}$-value of $5 \%$. This confirms the goodness of the fitting of the regression curves. Furthermore, the Runs test display also a balanced distribution of the data points around the regression curves (McWilliams 1990), with "not significant" deviations (Table 4).

\section{Soil Hydraulics Analysis}

The shape of the curves and the proportions of clay within the first two meters of the soil present several similarities, but also differences in the valley (Fig.2). It appears that despite of the various equations, clay proportions remains relatively high - between 20 and $30 \%$ - within the $2 \mathrm{~m}$ topsoil in both upstream and middle areas. This is in line with the permeability values, found smaller in these two cross-sections - $0.10 \pm 0.10$ $\mathrm{cm} / \mathrm{hr}$ - compared with downstream (Keïta et al. 2014). In the last area where most of the pedological homogeneity is found, and particularly in piezometers Pi4 and Pi10, a clay proportion peak of $30-40 \%$ is reached at around $1 \mathrm{~m}$, while it remains smaller before this depth.

The clay thickness and location are two of the most important factors that help in the choice of the type of subsurface drainage for the soil (Cannell et al. 1984; Foth 1990). When the peak followed a more pervious layer such as in the downstream area (Pi4 and Pi10, Fig. 2 ), but neither too close to the soil surface nor deeper than $2 \mathrm{~m}$, the classical Hooghoudt subsurface design can be applied (Coles 1968; Ritzema et al. 2008). 
Table 3 Downstream cross-section boreholes grain size distribution

\begin{tabular}{|c|c|c|c|c|c|c|c|c|}
\hline Sample No & $\begin{array}{c}\text { Depth start } \\
(\mathrm{m})\end{array}$ & $\begin{array}{c}\text { Depth end } \\
(\mathrm{m})\end{array}$ & $\begin{array}{c}\text { Clay } \\
\% \\
\end{array}$ & $\begin{array}{c}\text { Silt } \\
\% \\
\end{array}$ & $\begin{array}{c}\text { Gravel } \\
\% \\
\end{array}$ & $\begin{array}{c}\text { Sand total } \\
\% \\
\end{array}$ & $\begin{array}{c}\text { Total mater. } \\
\% \\
\end{array}$ & $\begin{array}{c}\begin{array}{c}\text { USDA Soil class } \\
\text { (Triangle) }\end{array} \\
\end{array}$ \\
\hline Piezo : & Pi5A & \multicolumn{2}{|c|}{ Geo coordinates UTM 30P : } & & $\mathrm{X}$ & 331114 & $\mathrm{Y}$ & 1174143 \\
\hline 25 & 0 & 0.1 & 37.1 & 35.7 & 0.1 & 27.2 & 100 & Clay loam \\
\hline 26 & 0.1 & 0.3 & 42.3 & 43.2 & 0.1 & 14.5 & 100 & Silty clay \\
\hline 27 & 0.3 & 0.7 & 3.6 & 24.8 & 0.1 & 71.6 & 100 & Sandy loam \\
\hline 28 & 0.7 & 1.6 & 32 & 32 & 0.2 & 36 & 100 & Clay loam \\
\hline 29 & 1.6 & 3.2 & 4.1 & 24.3 & 0.2 & 71.6 & 100 & Sandy loam \\
\hline 30 & 3.2 & 3.8 & 24.6 & 22.7 & 0.1 & 52.7 & 100 & Sandy clay loam \\
\hline 31 & 3.8 & 4.4 & 12.5 & 21.9 & 0 & 65.6 & 100 & Sandy loam \\
\hline 32 & 4.4 & 5 & 6 & 28.7 & 0 & 65.3 & 100 & Sandy loam \\
\hline Piezo : & Pi4A & \multicolumn{2}{|c|}{ Geo coordinates UTM 30P : } & & $\mathrm{X}$ & 331181 & $\mathrm{Y}$ & 1174212 \\
\hline 11 & 0 & 0.1 & 10.6 & 33.4 & 0 & 56 & 100 & Sandy loam \\
\hline 12 & 0.1 & 0.3 & 40.6 & 47.2 & 0.2 & 12.2 & 100 & Silty clay \\
\hline 13 & 0.3 & 0.5 & 42.1 & 45.3 & 0 & 12.6 & 100 & Silty clay \\
\hline 14 & 0.5 & 1.4 & 25 & 26.8 & 6.1 & 48.2 & 100 & Sandy clay loam \\
\hline 15 & 1.4 & 1.9 & 1.1 & 22 & 8.6 & 76.9 & 100 & Loamy sand \\
\hline Piezo : & Pi10A & \multicolumn{2}{|c|}{ Geo coordinates UTM 30P : } & & $\mathrm{X}$ & 331289 & $\mathrm{Y}$ & 1174320 \\
\hline 46 & 0 & 0.1 & 26.6 & 30.7 & 2.3 & 42.7 & 100 & Clay loam \\
\hline 47 & 0.1 & 0.3 & 22.1 & 36 & 1 & 41.9 & 100 & Clay loam \\
\hline 48 & 0.3 & 0.7 & 43.4 & 16 & 4 & 40.6 & 100 & Loam \\
\hline 49 & 0.7 & 1.2 & 19.4 & 18.3 & 26 & 62.3 & 100 & Silt loam \\
\hline 50 & 1.2 & 1.5 & 9.8 & 14.2 & 40.3 & 76 & 100 & Silt loam \\
\hline
\end{tabular}

Perforated pipes in the case of Tiéfora can be introduced around one meter depth within the soil (Christen and Ayars 2001). However, the persistence of a thick clay layer in the topsoil of the upstream and middle cross sections calls for application of alternative techniques such as "mole drainage" or permeability improvement practices (Schultz 1988). Mole drainage technique has been successfully applied against waterlogging and salt adversities for wide varieties of clay (Cannell et al. 1984; Robinson et al. 1987). Elsewhere, crack-making trenches were realized in the heavy, but non swelling clay (mainly illite) of the 165,000 ha agricultural land of IJsselmeerpolders in the Netherlands. This converted the almost impervious soil into a much lighter fertile medium, with an hydraulic conductivity of more than $100 \mathrm{~mm} /$ day (Schultz 1988). In Tiéfora the range of 10 to $40 \mathrm{meq} / 100 \mathrm{~g}$ of $C E C$ displays the soils as mainly composed of illite (Sokona et al. 2010) in which these techniques may be applied.

\section{CONCLUSIONS}

Clay distribution in a waterlogged soil valley bottom can be analyzed using comparative non-linear regression method, allowing choosing the most appropriate subsurface drainage technique. Our results show that, in the case of the irrigated rice soil of Tiéfora in Tropical Savannah, a quadratic curve is the most suitable to describe clay distribution (shape and location) in the soil. No unique equation could be found for the entire valley. It appeared that a soil layer made of $20-30 \%$ of clay and a thickness of $2 \mathrm{~m}$ persists in the top soils from upstream to the middle areas. Downstream, where the permeability 
Table 4 Regression parameters with $90 \%$ confidence interval

\begin{tabular}{lccccccccc}
\hline Piezo & Pi8 & Pi9 & Pi10 & Pi2 & Pi3 & Pi4 & Pi7 & Pi6 & Pi5 \\
\hline Selected regr & cubic & quadratic & quadratic & quadratic & quadratic & quadratic & quadratic & quadratic & quadratic \\
\hline \multicolumn{2}{l}{ Coefficients with $90 \%$ confidence interval } \\
$B_{0}$ & $20.2 \pm 0.6$ & $36.2 \pm 31.0$ & $19.2 \pm 32.3$ & $23.6 \pm 16.8$ & $32.8 \pm 5.9$ & $12.2 \pm 34.8$ & $33.6 \pm 15.4$ & $31.3 \pm 21.3$ & $33.3 \pm 22.2$ \\
$B_{1}$ & $-17.7 \pm 7.2$ & $7.7 \pm 40.6$ & $47.5 \pm 107.1$ & $2.0 \pm 31.9$ & $-6.7 \pm 13.1$ & $76.4 \pm 108.7-12.2 \pm 19.1$ & $-4.0 \pm 20.9$ & $-8.4 \pm 26.5$ \\
$B_{2}$ & $13.0 \pm 3.9$ & $-2.9 \pm 3.0$ & $-36.0 \pm 64.1$ & $-1.5 \pm 7.4$ & $-1.6 \pm 4.6$ & $-45.0 \pm 54.1$ & $1.8 \pm 3.5$ & $0.4 \pm 3.39$ & $0.8 \pm 5.3$ \\
$B_{3}$ & $-2.1 \pm 0.6$ & - & - & - & - & - & - & - & - \\
\hline$B_{1}, B_{2}, . ., B_{3}$ represent the coefficients of the quadratic (or cubic) regression equation Clay $(\%)=B_{0}+B_{1} d+B_{2} d^{2}+B_{3} d^{3}$
\end{tabular}

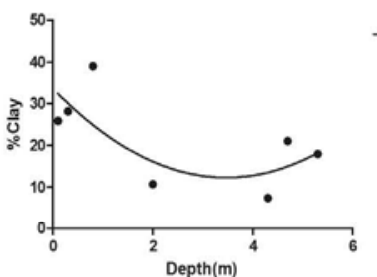

$\operatorname{Clay}(\%)=33.6-12.2 \cdot d+1.8 \cdot d^{2}$

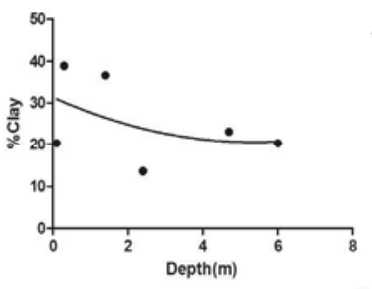

$\operatorname{Clay}(\%)=31.3-4.0 \cdot d+0.4 \cdot d^{2}$

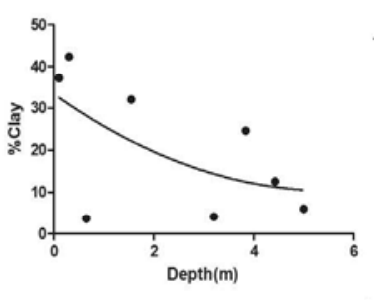

$\operatorname{Clay}(\%)=33.3-8.4 \cdot d+0.8 \cdot d^{2}$

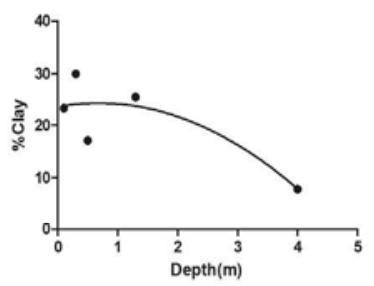

$\operatorname{Clay}(\%)=23.6+2.0 \cdot d-1.5 \cdot d^{2}$

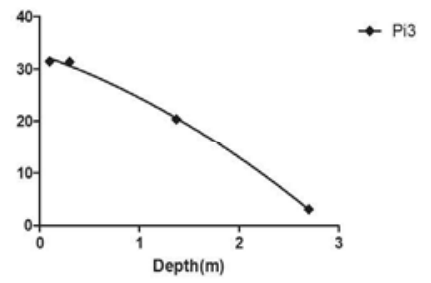

$\operatorname{Clay}(\%)=32.8-6.7 \cdot d-1.6 \cdot d^{2}$

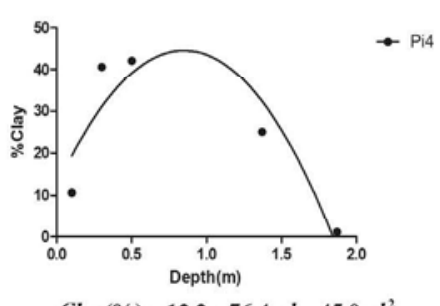

$\operatorname{Clay}(\%)=12.2+76.4 \cdot d-45.0 \cdot d^{2}$

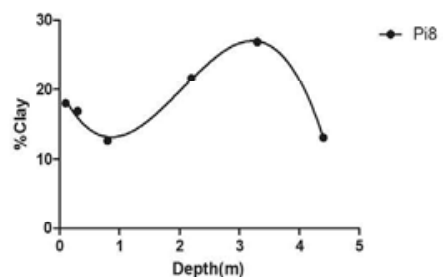

$\operatorname{Clay}(\%)=20.2-17.7 \cdot d+13.0 \cdot d^{2}-2.1 \cdot d^{3}$

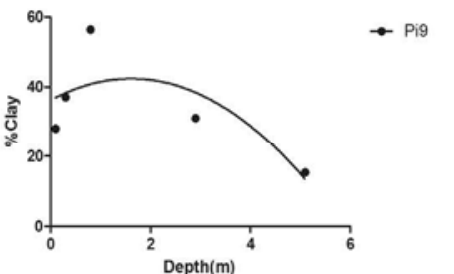

$\operatorname{Clay}(\%)=36.2+7.7 \cdot d-2.4 \cdot d^{2}$

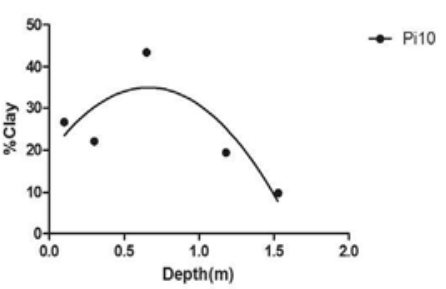

$\operatorname{Clay}(\%)=19.2+47.5 \cdot d-36.0 \cdot d^{2}$

Fig. 2 Regression best-fit curves and equations of the boreholes. The same names Pix were used for the boreholes and the above regression curves. The three top curves Pi7 Pi2 and Pi8 are in the upstream area; Pi6, Pi3 and Pi9 in the middle, and Pi5, Pi4 and Pi10 are in the downstream area. The best-fit curves are plotted for each borehole and the equations given at the bottom

is higher, this clay content reaches a peak of $40 \%$ but with a much lower thickness of $0.50 \mathrm{~m}$. In practice, these two configurations call for completely different subsurface drainage techniques. From upstream to the middle areas of the valley bottom, mole drainage and/or crack-making ditches will improve the permeability. In the downstream soils, a classical Hooghoudt perforated pipe drainage technique is appropriate to alleviate waterlogging.

\section{ACKNOWLEDGEMENT}

We are very grateful to the following institutions for the support provided to this research project: The Economic and Monetary Union of West Africa (UEMOA), The Netherlands Organization of International Cooperation in Higher Education (NUFFIC), French Development Agency (AFD), the International Foundation for Science, Sweden (IFS), and USAID. 


\section{REFERENCES}

Barron, V. and Torrent, J. (1986). Use of the KubelkaMunk theory to study the influence of iron oxides on soil colour. J. Soil Science, 37:499-510.

Becker, M. and Asch, F. (2005). Iron toxicity in rice conditions and management concepts. J. Plant Nurti. Soil Sci., 168:558-573.

Cannell, R.Q., Goss, M.J., Harris, G.L., Jarvis, M.G., Douglas, J.T., Howse, K.R. and Grice, S.L. (1984). A study of mole drainage with simplified cultivation for autumn-sown crops on a clay soil. The J. Agric. Sci., 102(3):539-559.

Christen, E.W. and Ayars, J.E. (2001). Subsurface drainage system design and management in irrigated agriculture: Best management practices for reducing drainage volume and salt load. Irrig. Sci., 21:35-43.

Coles, E.D. (1968). Some notes on drainage design procedure. Proc. of The South African Sugar Technologists' Association Manzini, Swaziland:189199.

Dembele, Y., Yacouba, H., Keïta, A. and Sally, H. (2012). Assessment of irrigation system performance in South-Western Burkina Faso. Irrig. and Drainage, 61(3):306-315.

Foth, H.D. (1990). Fondamentals of Soil Science. $8^{\text {th }}$ Ed. John Wiley \& Sons, USA.

Keïta, A. (2014). How to take a disturbed or undisturbed soil sample in a submerged soil at various depths. https://www.youtube.com/watch?v=JYVGS9BLNTo.

Keïta, A., Schultz, B., Yacouba, H. and Hayde, L.G. (2013a). Clay and ferrous iron stratifications in a Tropical Savannah Valley Bottom Soil under irrigated rice. Academia J. Agric. Research, 1(11):204-210.

Keïta, A., Yacouba, H., Hayde, L.G. and Schultz, B. (2014). Comparative non-linear regression - A case of infiltration rate increase from upstream in valley. Inter. Agrophysics, 28:303-310.

Keïta, A., Yacouba, H., Hayde, L.G. and Schultz, B. (2013b). A single-season irrigated rice soil presents higher iron toxicity risk in Tropical Savannah Valley Bottoms. Open J. Soil Sci., 3:314-322.

Kessler, J. and Oosterbaan, R.J. (1974). Determining hydraulic conductivity of soils. In Drainage principles and application, Ed. I. Public., ILRI. Wageninger, the Netherlands, 16:255-295.

McWilliams, T.P. (1990). A distribution-free test for symmetry based on a runs statistic. J. the American Statistical Association, 85(412):1130-1133.

Montgomery, D.C. and Runger, G.C. (2011). Applied Statistics and Probability for Engineers. Wiley and Sons, Inc.

Neumeyer, N. and Dette, H. (2003). Nonparametric comparison of regression curves: An empirical process approach. The Annals of Statistics, 31(3):880-920.
Nguu, N.V., Gibbons, J.W. and Dobson, R.L. (1988). Performance of rice (Oryza sativa) on slopes of inland valleys in West Africa. Elsevier Science Publishers B.V., 18:113-125.

Ogban, P. and Babalola, O. (2009). Characteristics, classification and management of inland valley bottom soils for crop production in sub-humid southwestern Nigeria. J. Ttropical Agriculture, Food, Environment and Extension, 8(1):1-13.

ONBAH. (1987). Study of Small Dams and Irrigation Schemes in the South-West Feasibility of the Site of Tiéfora.

Ouattara, B. S. (1992). Contribution to the Study of Iron and Sulfate Reducing Bacteria in the Kou Valley Bottom Rice Field. In Celular Biology, Vol. PhD, Université de Provence Aix-Marseille I. AixMarseille: 120.

Ritzema, H.P., Satyanarayana, T.V., Raman and Boonstra, J. (2008). Subsurface drainage to combat waterlogging and salinity in irrigated lands in India: Lessons learned in farmers' fields. Agric. Water Management, 95:179-189.

Robinson, M., Mulqueen, J. and Burke, W. (1987). On flows from a clay soil - Seasonal changes and the effect of mole drainage. J. Hydrology, 91(3-4):339350 .

Sahravat, K.L., Mulbah, C.K., Diatta, S., DeLaune, R.D., Patrick WH Jr., Singh, B.N. and Hones, M.P. (1996). The role of tolerant genotypes and plant nutrients in the management of iron toxicity in lowland rice. J. Agric. Schi. Cambridge, 126:143-149.

Schultz, B. (1988). Drainage measures and soil ripening during the reclamation of the former sea bed in the IJsselmeerpolders. In Proc. 15 ${ }^{\text {th }}$ European Regional Conference of ICID on Agricultural Water Management, International Commission on Irrigation and Drainage (ICID). Dubrovnik (Yugoslavia):197214.

Selley, R.C. (2000). Applied Sedimentology. $2^{\text {nd }}$ Edition. Academic Press, California, USA.

Shapiro, S. and Wilk, M.B. (1965). An analysis of variance test for normality : Complete samples. Biometrika 52(3-4):591-611.

Sokona, M.E.B., Boro, A., Hema, A. and Katiella, B. (2010). Diagnostic of the Irrigated Rice Scheme of Tiéfora, Province of Comoe, Region of the Cascades. Inter. Inst. for Water and Environ. Engrg. (2iE), Ouagadougou (Burkina Faso).

USDA. (1997). FM-5-410 - Millitary Soils Engineering. US Department of the Army, Washington, USA. 